\title{
Induced Tolerance Mechanism of Resistance in Rice to White Backed Plant Hopper through Zinc Application
}

\author{
Seema Tripathy* and Ladu Kishore Rath \\ Department of Entomology, College of Agriculture, Odisha University of Agriculture and \\ Technology, Bhubaneswar-751003, Odisha, India \\ *Corresponding author
}

A B S T R A C T

Keywords

Rice, White backed plant hopper, $\mathrm{Zn}$ EDTA, $\mathrm{ZnSO}_{4}$

Article Info

Accepted:

15 December 2019

Available Online:

20 January 2020
A pot culture experiment was undertaken during kharif, 2017 on evaluation of induced mechanism of zinc in rice for expression of tolerance against white backed plant hopper (WBPH) in the Department of Entomology, College of Agriculture, Odisha University of Agriculture and Technology, Bhubaneswar. It was revealed that basal application of Zn EDTA @ 40 $\mathrm{kg} / \mathrm{ha}$ along with its foliar spray @ 0.8\%, twice at 30 and 45 days after transplanting (DAT) $\left(\mathrm{T}_{6}\right)$ expressed fair degree of tolerance against WBPH. Zinc application delayed the wilting in treated plants as compared to control under high pest load. The functional plant loss index and per cent loss in grain and straw weight were also minimum in zinc treated plants comprising basal and foliar application as compared to sole application and control.

\section{Introduction}

Rice being the staple food of around $50 \%$ of the global population, has a demand for cultivation in years to come that will substantially add to achieve zero hunger (Thomas and Dobermann, 2002). However, this crop is subjected to various biotic challenges out of which plant hopper particularly WBPH pose serious threat. Nonavailability of commercial resistant variety compounds the challenge to mitigate WBPH population in rice. Moreover, the use of insecticides for WBPH control has been pushed to back foot demanding use of alternative approach to manage WBPH.

Induced resistance through abiotic elicitor in rice is one of the eco-friendly and potential approaches to enhance the defense power of the plant to combat against insect pest. Zinc is one such abiotic elicitor which is reported to induce defense mechanism in rice by regulating more than 300 enzymes (Marreiro et al., 2017) and promoting defensive pathway that lead to production of various 
secondary metabolites. Keeping this in view, the present investigation was carried out to ascertain the role of zinc in induction of resistance in rice to $\mathrm{WBPH}$.

\section{Materials and Methods}

Various pot culture experiments related to tolerance mechanism were undertaken in the Department of Entomology, College of Agriculture, Odisha University of Agriculture and Technology, Bhubaneswar. A susceptible rice variety (TN 1) was used as the test variety. Twenty one days old seedlings of TN 1 rice variety were transplanted on $10 \mathrm{~kg}$ capacity pots filled with fertilizer enriched puddled soil and calculated amount of treatment chemicals where basal applications were required. After application of recommended fertilizer dose and basal treatment in respective pots, they were covered by the Mylar cages of $45 \mathrm{~cm}$ height with top end covered by fine mesh muslin cloth. The plants were maintained as such under cage. At 30 and 45 DAT, foliar treatments were imposed on the plants. From 46 DAT the test insects were released into the cages as per the study requirement.

\section{Days to wilt}

In this experiment, 100 numbers of $2^{\text {nd }}$ and $3^{\text {rd }}$ instar nymphs of WBPH were released on the potted rice plants at 46 DAT, imposed with various treatments. The experiment was conducted with three replications. The period of time taken for wilting of plants after WBPH infestation was taken as a measure of tolerance. The plants were observed daily for plant health and vigour. The time taken by the plants to wilt in different treatments was recorded (Ramulamma, 2014).

\section{Loss in plant biomass}

In this study, 100 numbers of mixed populations of second and third instar nymphs of WBPH were introduced into treated plants kept in cages at 46 DAT. Similar set of uninfested plants were maintained simultaneously. The population pressure was applied for two weeks only. At harvest, grains of each replication as well as remaining plant parts were oven dried at $60^{\circ} \mathrm{C}$ for 72 hours, after which the weight of the samples of both infested and uninfested plants were recorded separately. Each treatment was replicated three times. The extent of loss in biomass production as a result of nymphal feeding was calculated based on the extent of loss in biomass production of infested and uninfested plant with respect to each treatment (Rath, 1995).

\section{Functional plant loss index (FPLI)}

To study the level of tolerance, 100 numbers of mixed populations of second and third instar nymphs of WBPH were introduced into each respective caged plant at 46 DAT. Similar set of uninfested plants were maintained simultaneously. The insects were allowed to feed on the plants till the control plant (without any zinc treatment) showed wilting and drying symptoms. At that time, all the plants were removed from the pots along with roots, washed thoroughly, air dried for three hours, then dried in an oven at $70^{\circ} \mathrm{C}$ for 60 hours and weighed. Each treatment was replicated three times. The FPLI was calculated based on the dry weight of infested and uninfested plant (Panda and Heinrichs, 1983).

FPLI $=1-\left[\frac{\text { Dry weight of infested plant }}{\text { Dry weight of uninfested plant }}\right] \times 100$

\section{Analysis of potassium and zinc content of rice plant}

Plants from pot culture experiment at 60 DAT were uprooted and washed with distilled water. These samples were first air dried and 
then again dried at $60^{\circ} \mathrm{C}$ in a hot-air oven for 24 hours. After drying it was cut into small pieces and made into powdered form. These powdered samples were sieved through a 100 mesh screen and stored in the sealed containers at $4^{0} \mathrm{C}$ for further use. Plant samples were digested by di-acid mixture i.e. $\mathrm{HClO}_{4}+\mathrm{HNO}_{3}$ (3:10). The di-acid digested samples were used to estimate the potassium and zinc content using digital flame photometer (Jackson, 1973) and atomic absorption spectrophotometer (Lindsey and Norwell, 1978), respectively.

\section{Statistical analysis}

The data thus, generated were subjected to angular transformation wherever required and then the data were analysed following the Completely Randomized Block Design (CRBD) procedure laid out by Gomez and Gomez (1984). The treatment variations were tested for significance by ' $F$ ' test. The standard error of means $\left(\mathrm{SE}_{(\mathrm{m})} \pm\right)$ and critical difference $(C D)$ at $5 \%$ level of significance were calculated following the standard procedure and treatment means were compared using CDs.

\section{Results and Discussion}

\section{Days to wilting}

Days to wilting caused due to differential insect load under different treatments was taken as a means of recording tolerance mechanism. It was evident from the Table 1 that the treatment $\mathrm{T}_{6}$ took 27.67 days to wilt under high pest load which was at par with $\mathrm{T}_{7}$ (25.00 days) and $\mathrm{T}_{5}$ (24.33 days). In other treatments, the duration for wilting of the plants ranged from 21.33 days in $\mathrm{T}_{1}$ to 23.00 days in $\mathrm{T}_{4}$. However, the control plants withered in 17.33 days which was completely different from rest of the treatments.

\section{Functional plant loss index}

The functional plant loss index was found to be the least $(27.80 \%)$ in $\mathrm{T}_{6}$ which was at par with most of the treatments except $\mathrm{T}_{1}(34.16$ $\%$ ) and $\mathrm{T}_{2}(33.48 \%)$ (Table 1). The control treatment had the highest value of FPLI $(69.51 \%)$ which was significantly different from rest of the treatments.

\section{Loss in plant biomass}

The data on loss in plant biomass (straw weight and grain weight) as a result of feeding by WBPH has been presented in Table 1. It can be witnessed from the Table 1 that the loss in straw weight was minimum in $\mathrm{T}_{7}(59.44 \%)$ which was statistically at par with most of the treatments excluding $\mathrm{T}_{1}$ and $\mathrm{T}_{2}$ in which the loss was 65.31 and 64.59 per cent, respectively. Maximum plant biomass loss was observed in $\mathrm{T}_{9}(70.43 \%)$ which was significantly different from all the zinc applied treatments except $T_{1}$.

It was further visualized that the grain weight loss was minimum in $\mathrm{T}_{7}(51.95 \%)$ which was at par with $\mathrm{T}_{6}(53.26 \%)$ and $\mathrm{T}_{8}(54.74 \%)$. The control treatment accounted for $78.49 \%$ grain weight loss which was significantly very high. Thus, it was clear that single application of either $\mathrm{ZnSO}_{4}$ or $\mathrm{Zn}$ EDTA did not account for higher grain weight loss than combined application of $\mathrm{ZnSO}_{4}$ and $\mathrm{Zn}$ EDTA.

\section{Potassium and zinc content of rice plant}

The data on potassium and zinc content of rice plants taken from pot culture experiment at 60 DAT has been presented in Table 2. It can be visualized from the data that potassium content was maximum in $\mathrm{T}_{7}(1.41 \%)$ which was at par with $\mathrm{T}_{8}(1.35 \%)$, whereas, $\mathrm{T}_{8}$ was at par with $\mathrm{T}_{5}(1.29 \%)$ and $\mathrm{T}_{6}(1.28 \%)$. 
Table.1 Influence of zinc application on various tolerance parameters of WBPH in rice

\begin{tabular}{|c|c|c|c|c|}
\hline \multirow[t]{2}{*}{ Treatment } & \multirow[t]{2}{*}{ Days to wilt* } & \multirow[t]{2}{*}{ FPLI $(\%)^{*}$} & \multicolumn{2}{|c|}{ Loss in plant biomass $(\%)$} \\
\hline & & & Straw weight* & Grain weight* \\
\hline $\mathrm{T}_{1}: \mathrm{ZnSO}_{4}$ basal $(25 \mathrm{~kg} / \mathrm{ha})$ & $21.33^{b c}$ & $34.16(35.75)^{b}$ & $65.31^{\mathrm{ab}}$ & $66.01^{b}$ \\
\hline$T_{2}:$ Zn EDTA basal (40 kg/ha) & $22.00^{b}$ & $33.48(35.34)^{\mathrm{b}}$ & $64.59^{\mathrm{bc}}$ & $65.27^{\mathrm{b}}$ \\
\hline $\begin{array}{l}\mathrm{T}_{3}: \mathrm{ZnSO}_{4} \text { foliar spray @ } 0.5 \%(5 \mathrm{~g} / \mathrm{l} \text { of water }) \text { twice at } \\
30 \text { and } 45 \mathrm{DAT}\end{array}$ & $22.67^{b}$ & $31.29(33.98)^{b c}$ & $63.72^{\mathrm{bc}}$ & $62.99^{\mathrm{bc}}$ \\
\hline $\begin{array}{l}\text { T}_{4}: \text { Zn EDTA Foliar spray @ } 0.8 \% \text { (8g/l of water) } \\
\text { twice at } 30 \text { and } 45 \text { DAT }\end{array}$ & $23.00^{\mathrm{b}}$ & $31.37(34.05)^{\mathrm{bc}}$ & $64.21^{\mathrm{bc}}$ & $61.70^{\mathrm{bc}}$ \\
\hline $\begin{array}{l}\mathrm{T}_{5}: \mathrm{ZnSO}_{4} \text { basal }(25 \mathrm{~kg} / \mathrm{ha})+\mathrm{ZnSO}_{4} \text { foliar spray @ } \\
0.5 \%(5 \mathrm{~g} / \mathrm{l} \text { of water }) \text { twice at } 30 \text { and } 45 \mathrm{DAT}\end{array}$ & $24.33^{\mathrm{ab}}$ & $28.21(32.07)^{\mathrm{c}}$ & $63.31^{\mathrm{bc}}$ & $58.56^{\mathrm{cd}}$ \\
\hline $\begin{array}{l}\text { T6: Zn EDTA basal }(40 \mathrm{~kg} / \mathrm{ha})+\mathrm{Zn} \text { EDTA Foliar } \\
\text { spray@ } 0.8 \%(8 \mathrm{~g} / \mathrm{l} \text { of water }) \text { twice at } 30 \text { and } 45 \mathrm{DAT}\end{array}$ & $27.67^{\mathrm{a}}$ & $27.80(31.80)^{\mathrm{c}}$ & $61.15^{\mathrm{bc}}$ & $53.26^{\mathrm{de}}$ \\
\hline $\begin{array}{l}\mathrm{T}_{7}: \mathrm{ZnSO}_{4} \text { basal}(25 \mathrm{~kg} / \mathrm{ha})+\mathrm{Zn} \text { EDTA Foliar spray @ } \\
0.8 \%(8 \mathrm{~g} / \mathrm{l} \text { of water }) \text { twice at } 30 \text { and } 45 \mathrm{DAT}\end{array}$ & $25.00^{\mathrm{ab}}$ & $29.73(33.03)^{b c}$ & $59.44^{\mathrm{c}}$ & $51.95^{\mathrm{e}}$ \\
\hline $\begin{array}{l}\mathrm{T}_{8}: \mathrm{Zn} \text { EDTA basal }(40 \mathrm{~kg} / \mathrm{ha})+\mathrm{ZnSO}_{4} \text { foliar spray } \\
@ 0.5 \%(5 \mathrm{~g} / \mathrm{l} \text { of water }) \text { twice at } 30 \text { and } 45 \mathrm{DAT}\end{array}$ & $22.67^{b}$ & $28.49(32.24)^{b c}$ & $62.23^{\mathrm{bc}}$ & $54.74^{\mathrm{de}}$ \\
\hline $\mathbf{T}_{9}$ : Control & $17.33^{\mathrm{c}}$ & $69.51(56.57)^{\mathrm{a}}$ & $70.43^{\mathrm{a}}$ & $78.49^{\mathrm{a}}$ \\
\hline $\mathbf{S E}_{(\mathbf{m})} \pm$ & 1.358 & 1.031 & 1.740 & 2.006 \\
\hline C.D.(0.05) & 4.07 & 3.09 & 5.17 & 5.96 \\
\hline
\end{tabular}

*Mean of three replications

Figures in the parentheses are angular transformed values

Means followed by the same letter are not significantly different from each other 
Table.2 Potassium and zinc content of rice plant sample taken from pot culture experiment

\begin{tabular}{|c|c|c|c|c|}
\hline Treatment & $\begin{array}{c}\text { Potassium } \\
\text { content } \\
(\%)\end{array}$ & $\begin{array}{c}\text { Increase over } \\
\text { control } \\
(\%)\end{array}$ & $\begin{array}{l}\text { Zinc content } \\
\quad(\mathbf{p p m})\end{array}$ & $\begin{array}{c}\text { Increase over } \\
\text { control } \\
(\%)\end{array}$ \\
\hline $\mathrm{T}_{1}: \mathrm{ZnSO}_{4}$ basal $(25 \mathrm{~kg} / \mathrm{ha})$ & $1.21^{\mathrm{cd}}$ & 11.01 & $16.80^{\text {de }}$ & 5.00 \\
\hline $\mathrm{T}_{2}:$ Zn EDTA basal (40 kg/ha) & $1.14^{\mathrm{de}}$ & 4.59 & $20.20^{\mathrm{abc}}$ & 26.25 \\
\hline $\begin{array}{l}\mathrm{T}_{3}: \mathrm{ZnSO}_{4} \text { foliar spray @ } 0.5 \%(5 \mathrm{~g} / \mathrm{l} \text { of water }) \text { twice } \\
\text { at } 30 \text { and } 45 \mathrm{DAT}\end{array}$ & $1.21^{\mathrm{cd}}$ & 11.00 & $18.50^{\mathrm{cd}}$ & 15.62 \\
\hline $\begin{array}{l}T_{4}: \text { Zn EDTA Foliar spray @ } 0.8 \% \text { (8g/l of water) } \\
\text { twice at } 30 \text { and } 45 \text { DAT }\end{array}$ & $1.23^{\mathrm{cd}}$ & 12.84 & $19.10^{\mathrm{bc}}$ & 19.37 \\
\hline $\begin{array}{l}\mathrm{T}_{5}: \mathrm{ZnSO}_{4} \text { basal }(25 \mathrm{~kg} / \mathrm{ha})+\mathrm{ZnSO}_{4} \text { foliar spray @ } \\
0.5 \%(5 \mathrm{~g} / \mathrm{l} \text { of water }) \text { twice at } 30 \text { and } 45 \mathrm{DAT}\end{array}$ & $1.29^{\mathrm{bc}}$ & 18.35 & $21.00^{\mathrm{ab}}$ & 31.25 \\
\hline $\begin{array}{l}\text { T}_{6}: \text { Zn EDTA basal }(40 \mathrm{~kg} / \mathrm{ha})+\mathrm{Zn} \text { EDTA Foliar } \\
\text { spray@ } 0.8 \%(8 \mathrm{~g} / \mathrm{l} \text { of water }) \text { twice at } 30 \text { and } 45 \mathrm{DAT}\end{array}$ & $1.28^{\mathrm{bc}}$ & 17.43 & $21.30^{\mathrm{a}}$ & 33.12 \\
\hline $\begin{array}{l}\mathrm{T}_{7}: \mathrm{ZnSO}_{4} \text { basal }(25 \mathrm{~kg} / \mathrm{ha})+\mathrm{Zn} \text { EDTA Foliar spray } \\
\text { @ } 0.8 \%(8 \mathrm{~g} / \mathrm{l} \text { of water }) \text { twice at } 30 \text { and } 45 \mathrm{DAT}\end{array}$ & $1.41^{\mathrm{a}}$ & 29.36 & $20.50^{\mathrm{ab}}$ & 28.13 \\
\hline $\begin{array}{l}\text { T}_{8}: \mathrm{Zn} \text { EDTA basal }(40 \mathrm{~kg} / \mathrm{ha})+\mathrm{ZnSO}_{4} \text { foliar spray } \\
\text { @ } 0.5 \%(5 \mathrm{~g} / \mathrm{l} \text { of water }) \text { twice at } 30 \text { and } 45 \mathrm{DAT}\end{array}$ & $1.35^{\mathrm{ab}}$ & 23.85 & $21.30^{\mathrm{a}}$ & 33.12 \\
\hline T9: Control & $1.09^{\mathrm{e}}$ & - & $16.00^{\mathrm{e}}$ & - \\
\hline $\mathbf{S E}_{(\mathbf{m})} \pm$ & 0.029 & & 0.643 & \\
\hline C.D.(0.05) & 0.09 & & 1.91 & \\
\hline
\end{tabular}

Means followed by the same letter are not significantly different from each other 
Similarly it was also observed that the potassium content in $\mathrm{T}_{1}, \mathrm{~T}_{2}$, and $\mathrm{T}_{4}$ was also at par with $\mathrm{T}_{6}$. But in all the treatments comprising zinc supplementation, the potassium content was significantly higher than the control treatment (1.09\%).

It can be depicted from Table 2 that zinc content was maximum in $\mathrm{T}_{6}$ as well as in $\mathrm{T}_{8}$ i.e. $21.30 \mathrm{ppm}$, which was at par with $\mathrm{T}_{2}$ (20.20 ppm), $\mathrm{T}_{7}(20.50 \mathrm{ppm})$ and $\mathrm{T}_{5}(21.00$ ppm) and $\mathrm{T}_{7}(20.50 \mathrm{ppm})$, respectively. The treatment $\mathrm{T}_{9}$ (control) had significantly lowest zinc content $(16.00 \mathrm{ppm})$ which was significantly different from all the treatments.

Pot culture studies were conducted to assess the induced tolerance effect in rice plants in terms of duration to wilting, FPLI and loss in plant biomass being influenced by zinc application (Table 1). Enhancement in duration of wilting of rice plants under exposure of higher pest load above ETL is considered as a tolerance mechanism (Jhansilakshmi et al., 2012). Alagar and Suresh (2007) have also observed that resistant variety took 27-31 days for wilting as compared to susceptible TN1 (18.2 days). In the present study, we observed that when TN 1 plants died completely in 17.33 days, at same population load wilting started in $\mathrm{T}_{6}, \mathrm{~T}_{5}$ and $\mathrm{T}_{7}$ treatments nearly 10 days later. This indicated a probable withstanding capacity of zinc treated plants against high hopper infestation. Hence, the present finding is in line of conformity with the above authors.

It was also observed that the FPLI was minimum $(27.80 \%)$ in $\mathrm{T}_{6}$ which was significantly not different from rest of the treatments except the basal treatments. Highest plant loss index was seen in control $(69.51 \%)$. Biomass loss due to herbivory is a mechanism of tolerance assessment. Plant biomass loss is directly proportional to WBPH feeding activity and less loss in $T_{3}$ to
$\mathrm{T}_{8}$ even at high pest load may be attributable to less insect activity and subsequent less feeding or a compensatory mechanism induction due to zinc application. Alagar and Suresh (2006) also have witnessed a similar phenomenon.

The data on zinc content of rice plant at maximum insect activity has been presented in Table 2. It was quite conspicuous that zinc content was more in all the zinc treatments as compared to control. The treatments like $\mathrm{T}_{6}$ and $\mathrm{T}_{7}$ recorded more zinc content within all zinc treatments accounting for 26.75 and $22.43 \%$ increase in zinc content. The zinc content of the pot culture plant samples also exhibited a similar response as that of field data, where, $\mathrm{T}_{6}$ and $\mathrm{T}_{8}$ caused each of $33.12 \%$ increase in zinc content as compared to control. Higher zinc content due to application of $\mathrm{Zn}$ EDTA and $\mathrm{ZnSO}_{4}$ in rice has been evidenced by Karak et al., (2005). Enhancement of Potassium content in plants confers resistance to many phytophagous insects. Potassium is responsible for grain boldness which is a plants' compensating mechanism to feeding insect (Liu et al., 2011). In the present study, the increase in potassium content due to zinc application might have acted synergistically as a result of which application of zinc to rice plants induced resistance phenomenon against WBPH. Srivastava et al., (2016) also observed that foliar application of zinc increased the zinc and potash concentration in flag leaves and straw of rice significantly because zinc fertilizer enhanced the utilization of potassium content of soil and ultimately resulting in higher uptake of potash. Thus, our finding corroborate with the findings of above authors.

\section{Acknowledgement}

Authors are gratefully acknowledged to the Department of Science and Technology 
(DST) (Govt. of India), New Delhi for providing financial assistance for this research work through INSPIRE Fellowship.

\section{References}

Alagar, M., and Suresh, S. 2006. Tolerance studies on selected rice genotypes against brown plant hopper, Nilaparvatalugens (Stal). Indian Journal of Plant Protection. 34(1): 15-18.

Alagar, M., and Suresh, S. 2007. Population build up of brown plant hopper, Nilaparvatalugens on selected rice genotypes. Indian Journal of Plant Protection. 35(1): 32-35.

Fairhurst, T., and Dobermann, A. 2002. Rice in the global food supply. Better Crops International. 16: 3-6.

Gomez, K.A., and Gomez, A.A. 1984. Statistical Procedures for Agricultural Research, John Wiley and Sons, New York, pp 680.

Jackson, M.L. 1973. Soil Chemical Analysis, Prentice, Hall of Indian Private Limited, New Delhi, pp 498.

Jhansi Lakshmi, V., Ram, T., Chirutkar, P.M., and Sailaja, V. 2012. Mechanisms of resistance to rice plant hoppers in wild rices and their accessions, paper presented in international conference on plant health management for food security, Directorate of Rice Research, Hyderabad, 28-30 ${ }^{\text {th }}$ November, pp 27-28.

Karak, T., Singh, U.K., Das, S., Das, D.K., and Kuzyakov, Y. 2005. Comparative efficacy of $\mathrm{ZnSO}_{4}$ and $\mathrm{Zn}$ EDTA application for fertilization of rice (Oryza sativa L.).Archives of Agronomy and Soil Science. 51: 253-264.
Lindsay, W.L., and Norwell, W.R. 1978. Development of DTPA soil test for zinc, iron, manganese and copper.Soil Science Society of America Journal.42: 421-428.

Liu, L.J., Chang, E.H., Fan, M.M., Wang, Z.Q., and Yang, J.C. 2011.Effect of potassium and calcium on root exudates and rain quality during grain filling. Acta Agronomica Sinica. 37: 661-669.

Marreiro, D.D., Cruz, K.J., Morais, J.B., Beserra, J.B., Severo, J.S., and de Oliveira, A.R. 2017. Zinc and oxidative stress: Current Mechanisms. Antioxidants (Basel). 6(2):24.

Panda, N., and Heinrichs, E.A. 1983. Levels of tolerance and antibiosis in rice varieties having moderate resistance to the brown plant hopper, Nilaparvatalugens (Stal) (Hemiptera: Delphacidae). Environmental Entomology. 12: 1204-1214.

Ramulamma, A. 2014.Host plant resistance in paddy to brown plant hopper, Nilaparvatalugens (Stal). M.Sc. (Ag.) thesis submitted Acharya N.G. Ranga Agricultural University, Rajendranagar, Hyderabad, pp 82.

Rath, L.K. 1995. Studies on host plant resistance in rice to the white backed plant hopper Sogatella furcifera (Horvath) (Homoptera: Delphacidae), Ph.D. thesis submitted to Banaras Hindu University, Varanasi, pp 175.

Srivastava, P.C., Ansari, U.I., Pachauri, S.P., and Tyagi, A.K. 2016. Effect of zinc application methods on apparent utilization efficiency of zinc and potassium fertilizers under rice-wheat rotation. Journal of Plant Nutrition. 39(3): 348-364.

\section{How to cite this article:}

Seema Tripathy and Ladu Kishore Rath. 2020. Induced Tolerance Mechanism of Resistance in Rice to White Backed Plant Hopper through Zinc Application. Int.J.Curr.Microbiol.App.Sci. 9(01): 1870-1876. doi: https://doi.org/10.20546/ijcmas.2020.901.209 